\title{
KOMUNIKASI MASSA SEBAGAI MEDIA DAKWAH
}

\author{
Safrizal
}

\begin{abstract}
Abstrak
Sejarah media penyiaran dunia dimulai ketika ahli fisika Jerman bernama Heinrich Hertz pada tahun 1887 berhasil mengirim dan menerima gelombang radio. Upaya Hertz itu kemudian dilanjutkan oleh Guglielmo Marconi (1874-1937) dari Italia yang sukses mengirimkan sinyal morse berupa titik dan garis dari sebuah pemancar kepada suatu alat penerima. Sinyal yang dikirimkan Marconi berhasil menyeberangi Samudra Atlantik pada tahun 1901 dengan menggunakan gelombang elektromagnetik. Stasiun radio pertama muncul ketika seorang tehnik bernama Frank Conrad di Pittsburgh AS, pada tahun 1920 secara iseng-iseng sebagai bagian dari hobi, membangun sebuah pemancar radio di garasi rumahnya. Conrad menyiarkan lagu-lagu, mengumumkan hasil pertandingan olahraga dan menyiarkan instrumen musik yang dimainkan putranya sendiri. Dalam waktu singkat, Conrad berhasil mendapatkan banyak pendengar seiring dengan meningkatnya penjualan pesawat radio ketika itu. Stasiun radio yang dibangun Conrad itu kemudian diberi nama KDKA dan masih tetap mengudara hingga saat ini, menjadikannya sebagai stasiun tertua di Amerika dan mungkin juga didunia.

Di Provinsi Aceh perkembangan siaran radio saat ini berkembang dengan pesat mengikuti perubahan zaman dan aturan yang berlaku. Sampai saat ini program-program pada siaran Radio Swasta masih banyak diminati oleh pendengarnya disetiap lapisan masyarakat mulai dari kalangan anak-anak, remaja, hingga dewasa. Program-program siaran Radio Swasta di Aceh khususnya kabupaten Aceh Tamiang banyak menyiarkan siaran-siaran yang berbau Islami hingga siaran-siaran umum dan Pemerintahan, sehingga berbagai program radio menjadi lebih baik dan sesuai. Program Penyiaran tentang KeIslaman tersebut disiarkan pada Radio Birama Indah 103,7 FM untuk disiarkan di wilayah Aceh Tamiang guna mendukung terciptanya ketentraman dan kesejahteraan berdasarkan ajaran Islam yang diajarkan oleh baginda Rasulullah SAW sebagai suri tauladan bagi kita semua khususnya umat Islam diseluruh penjuru dunia.
\end{abstract}

\section{Kata Kunci: Komunikasi Massa, Dakwah}

\section{A. Komunikasi dan Komunikasi Massa}

Secara etimologis, komunikasi berasal dari perkataan latin communication. Istilah ini bersumber dari perkataan communis yang berarti sama, sama disini maksudnya sama makna atau sama arti. Jadi komunikasi terjadi apabila terdapat kesamaan makna mengenai suatu pesan yang disampaikan oleh komunikator dan diterima oleh komunikan. (Onong Uchjana Effendy,2003:30)

Menurut pendapat yang lain, secara etimologi (bahasa), kata "komunikasi” berasal dari bahsa Inggris "communication" yang mempunyai akar kata dari bahasa Latin “comunicare”, kata ini memiliki tiga kemungkinan arti yaitu :

1. “to make common" atau membuat sesuatu menjadi umum.

2. “cum+ munus" berarti saling memberi sesuatu sebagai hadiah. 
3. "cum+ munire" yaitu membangun pertahanan bersama.

Sedangkan secara epistemologis (istilah), terdapat ratusan uraian eksplisit (nyata) dan implisit (tersembunyi) untuk menggambarkan defenisi komunikasi. (Muhammad Mufid,2007:1)

Hakikat komunikasi adalah proses pernyataan antar manusia. Yang dinyatakan itu adalah pikiran atau perasaan seseorang kepada orang lain dengan menggunakan bahasa sebagai alat penyalurnya. Dalam "bahasa" komunikasi pernyataan dinamakan pesan (message), orang yang menyampaikan pesan disebut komunikator (communicator) sedangkan orang yang menerima pernyataan di beri nama komunikan (communicate). Komunikasi berarti proses penyampaian pesan oleh komunikator kepada komunikan.(Onong Uchjana Effendy,2003:28)

Komunikasi massa (mass communication) ialah komunikasi melalui media massa modern yang meliputi surat kabar yang mempunyai sirkulasi yang luas, siaran radio dan televise yang ditujukan kepada umum, dan film yang dipertunjukkan di gedung-gedung bioskop. Komunikasi massa menyiarkan informasi, gagasan dan sikap kepada komunikan yang beragam dalam jumlah yang banyak dengan menggunakan media. (Onong Uchjana Effendy,2003:79-80)

\section{Karakteristik Komunikasi Massa}

- Komunikasi massa bersifat umum

Pesan komunikasi yang disampaikan melalui media massa adalah terbuka untuk semua orang. Benda-benda tercetak, film, radio dan televise apabila dipergunakan untuk keperluan pribadi dalam lingkungan organisasi yang tertutup, tidak dapat dikatakan komunikasi massa. Meskipun pesan komunikasi massa bersifat umum dan terbuka, sama sekali terbuka juga jarang diperoleh, disebabkan faktor yang bersifat paksaan yang timbul karena struktur sosial. Pengawasan terhadap faktor tersebut dapat dilakukan secara resmi sejauh bersangkutan dengan larangan dalam bentuk hukum, terutama yang berhubungan dengan penyiaran keluar negeri.

- Komunikan bersifat heterogen

Massa dalam komunikasi massa terjadi dari orang-orang yang heterogen yang meliputi penduduk yang bertempat tinggal dalam kondisi yang sangat berbeda, dengan kebudayaan yang beragam, berasal dari berbagai lapisan masyarakat, mempunyai pekerjaan yang berjenis-jenis maka oleh karena itu mereka berbeda pula dalam kepentingan, standar hidup dan derajat kehormatan, kekuasaan dan pengaruh. 
Komunikan dalam komunikasi adalah sejumlah orang yang disatukan oleh suatu minat yang sama yang mempunyai bentuk tingkah laku yang sama dan terbuka bagi pengaktifan tujuan yang sama; meskipun demikian orang-orang yang tersangkut tadi tidak saling mengenal, berinteraksi secara terbatas dan tidak terorganisasikan. Komposisi komunikan tersebut tergeser-geser terus menerus, serta tidak mempunyai kepemimpinan atau perasaan identitas.

- Media massa menimbulkan keserempakan

Yang dimaksudkan dengan keserempakan ialah keserempakan kontak dengan sejumlah besar penduduk dalam jarak yang jauh dari komunikator, dan penduduk tersebut satu sama lainnya berada dalam keadaan terpisah. Radio dan televisi dalam hal ini melebihi media tercetak, karena terakhir dibaca pada waktu yang berbeda dan lebih selektif.

Ada dua segi penting mengenai kontak yang langsung itu; pertama kecepatan yang lebih tinggi dari penyebaran dan kelangsungan tanggapan, kedua; keserempakan adalah penting untuk keseragaman dalam seleksi dan interpretasi pesan-pesan. Tanpa komunikasi massa, hanya pesan-pesan yang sangat sederhana saja yang disiarkan tanpa perubahan dari orang yang satu ke orang yang lain.

- Hubungan komunikator-komunikan non pribadi

Hal ini dikarenakan komunikan yang anonim dicapai oleh orang-orang yang dikenal hanya dalam peranannya yang bersifat umum sebagai komunikator. Sifat non pribadi ini timbul disebabkan teknologi dari penyebaran yang massal dan sebagian lagi dikarenakan syarat-sayarat bagi peranan komunikator yang bersifat umum.(Onong Uchjana Effendy,2003:81-83)

\section{The Bullet Theory dan Agenda Setting Theory}

- The Bullet Theory

Teori peluru (the bullet theory of communication) merupakan konsep awal sebagai efek komunikasi massa. Dikalangan para teoritis atau pakar komunikasi ditahun 1970-an dinamakan hypodermic needle theory yang dapat diterjemahkan sebagai teori jarum hipodermik. Teori ini, pada awalnya ditampilkan sejak tahun 1950-an, setelah peristiwa penyiaran kaleidoskop stasiun radio CBS di Amerika Serikat, berjudul "The Invasion From Mars)",.

Teori ini mengasumsikan bahwa para pengelola media dianggap sebagai orang yang lebih pintar dari pada aundien. Oleh karenanya, audien bisa dikelabui, ditundukkan bahkan bisa dibentuk dengan cara apapun yang dikehendaki media. Jason dan Ane Hill 
menyatakan bahwa media massa dalam teori jarum hipodermik ini mempunyai efek langsung “disuntikkan” kedalam ketidaksadaran audience.(Syukur Kholil,2011:99)

Wilbur Scramm tahun 1950-an, pernah mengatakan bahwa komunikator dapat menembakkan peluru komunikasi yang begitu ajaib kepada khalayak yang pasif dan tidak berdaya namun pada tahun 1970-an, Scramm meminta kepada para peminatnya agar teori peluru komunikasi itu dianggap tidak ada, sebab khalayak yang menjadi sasaran media massa itu ternyata tidak pasif. (Onong Uchjana Effendy,2003:265)

Statement Schramm tentang pencabutan teorinya itu didukung oleh Paul Lazarsfeld dan Rauymond Bauer. Beliau mengatakan jika khalayak diterpa peluru komunikasi, mereka tidak jatuh terjerembak. Kadang-kadang peluru itu tidak menembus. Adakalanya, efek yang timbul sangat berlainan dengan tujuan sipenembak. Sering kali pula, khalayak yang digunakan yang dijadikan sasaran senang untuk ditembak. (Onong Uchjana Effendy,2003:81-83)

Namun demikian, pandangan teori peluru ajaib ini diperkuat oleh peneliti komunikasi pada tahun 1930-an dan awal tahun 1940-an. Seperti Carl I. Hovland, seorang profesor Psikologi Pendidikan dari University Yale. Dia menemukan bahwa media massa mempunyai pengaruh yang kuat terhadap khalayak. (Syukur Kholil,2007:99)

Karenanya berdasarkan berbagai asumsi diatas pesan-pesan komunikasi Islam yang disampaikan melalui medi massa dapat memberi pengaruh bagi khalayak penggunanya. Karenanya sudah semestinya media massa digunakan semaksimal mungkin untuk menyampaikan pesan-pesan islam keseluruh penjuru dunia. Sehingga nilai-nilai ajaran agama islam dapat dipahami serta diamalkan oleh umat manusia.

- Agenda Setting Theory

Teori agenda setting diperkenalkan oleh Maxwell Mc Combs dan Donald L. Shaw. Menurut teori ini, media massa tidak dapat mempengaruhi orang untuk mengubah sikap, tetapi media massa cukup berpengaruh terhadap apa yang dipikirkan orang. Ini berarti media massa mempengaruhi persepsi khalayak tentang apa yang dianggap penting. (Jalaluddin Rakhmat, 2007:200)

Teori ini menyatakan tidak selalu berhasilnmemberi tahu apa yang kita pikir, tetapi media tersebut benar-benar berhasil memberitahu kita berpikir tentang apa. Media massa selalu mengarahkan kita pada apa yang harus kita lakukan. Media memberikan agendaagenda melalui pemberitaan sedangkan masyarakat mengikutinya. 
Menurut pendapat Chaffe dan Berger ada beberapa catatan yang perlu dikemukakan untuk memperjelas teori ini. (Nuruddin, 2007:197)

a. Teori ini mempunyai kekuatan penjelas menerangkan mengapa orang sama-sama menganggap penting suatu isu.

b. Teori ini mempunyai kekuatan memprediksi bahwa jika orang-orang mengekspos pada satu media yang sama, mereka akan merasa isu yang sama tersebut penting.

c. Teori itu dapat dibuktikan salah jika orang-orang tidak mengekspos media yang sama maka mereka tidak akan mempunyai kesamaan bahwa isu media itu lebih penting.

Model agenda setting ini mangasumsikan adanya hubungaan positif antara penilaian yang diberikan media pada suatu persoalan dengan perhatian yang diberikan khalayak pada persoalan itu. Singkatnya, apa yang dianggap penting oleh media, akan di anggap penting pula oleh masyarakat. Apa yang dilupakan media, akan luput pula dari perhatian masyarakat.

Oleh karena itu, untuk mengaktualisasikan nilai-nilai islam dalam kehidupan umat manusia, karenanya media harus menyiarkan sebanyak-banyaknya pesan-pesan yang bernuansa islam, salah satunya dapat dilakukan melalui radio, menurut teori ini masyarakat akan memandang pesan-pesan sebagai sesuatu hal yang penting dan menarik sehingga masyarakat berusaha memahami dan kemudian mengamalkan pesan-pesan yang di agendakan.

\section{B. Radio Siaran Sebagai Media Dakwah}

Menurut Peraturan Pemerintah No : 55 tahun 1977, Radio Siaran adalah pemancar radio yang langsung ditujukan kepada umum dalam bentuk suara dan mempergunakan gelombang radio sebagai media.(Onong Uchjana Effendy,1993:187) Melalui radio setiap gagasan propaganda dapat dengan mudah ditulis diatas secarik kertas kemudian tinggal dibacakan didepan corong sebanyak kali yang diinginkan dan pelaksanaannya berlangsung dengan mudah.

\section{Sejarah Perkembangan Radio}

Perkembangan radio dimulai dari penemuan phonograph (gramafon), yang juga bias digunakan memainkan rekaman, oleh Edison pada tahun 1877. Pada saat yang sama James Clerk Maxwell dan Helmholtz Hertz melakukan eksperimen elektromagnetik untuk mempelajari fenomena yang kemudian dikenal sebagai gelombang radio. Keduanya menemukan bahwa gelombang radio merambat dalam bentuk bulatan, sama seperti ketika kita menjatuhkan sesuatu pada air yang tenang. Riak gelombang yang dihasilkan akibat 
benda yang jatuh tersebut secara sederhana dapat menggambarkan bagaimana gelombang radio merambat. Jumlah gelombang radio diukur dengan satuan Hertz.

Marconi merupakan orang yang kemudian memanfaatkan kedua penemuan diatas untuk mengembangkan system komunikasi melalui gelombang radio pada tahun 1896. Usaha Marconi ketika itu baru berhasil pada tahap mengirimkan gelombang radio secara on and off (nyala dan mati), sehingga baru bias menyiarkan kode telegraf. Lee De Frost lalu menemukan vacuum tube pada tahun 1906. Vacuum tube mampu menangkap signal radio sekalipun lemah. Pada tahun yang sama Reginald Fessenden menciptakan "penyiaran" pertama dengan menggunakan telepon sebagai mikrofon. Siaran radio secara regular dimulai pada tahun 1912 oleh Charles Herrold.

Sampai disini, siaran radio belum dilihat sebagai kegiatan ekonomi. Baru pada tahun 1919 Frank Conrad secara regular menyiarkan produk-produk sebuah department store di AS. Akibat siaran ini, angka penjualan pesawat radio meningkat tajam hingga 500 ribu buah pada tahun 1923, atau meningkat 5 kali lipat dibandingkan tahun sebelumnya.

Perkembangan penyiaran radio selanjutnya dilanjutkan dengan penayangan iklan pada siaran tahun 1922oleh stasiun AT\&T di AS. AT\&T memakai system operasi telepon, yakni semua pengiklan dikenai sejumlah tariff siaran yang disebut toll broadcasting. System berjaringan selain memberi keuntunganpada pembuatan program berkualitas dengan biaya murah (karena ditanggung tiap stasiun dalam jaringan) seperti music dan drama, juga menciptakan pasar pengiklan yang lebih luas.

Radio kemudian memasuki masa keemasan, yakni masa sebelum perang Dunia II. Ketika itu radio adalah wahana informasi, hiburan sekaligus teman. Bagi individu ketika itu radio begitu special. Banyak stasiun ketika itu memiliki sendiri staf orchestra untuk memainkan jaz atau program symphonic. Bahkan tak jarang, studio juga memiliki kelompok pemain drama. Tiap stasiun memiliki pendengar loyal tersendiri. Begitu juga dengan dunia penyiaran ketika itu.

Pada awal tahun 1960, siaran radio memasuki masa penting dengan dikembangkannya teknologi siaran menggunakan frekuensi FM. Teknologi FM sebenarnya telah ditemukan pada tahun 1930-an, namun ketika itu baru sedikit saja pesawat radio bias menerima siaran FM. Walaupun daya jangkau lebih rendah, namun dibandingkan AM, siaran FM menghasilkan suara yang lebih jernih dengan efek suara stereo. Kelebihan ini pada gilirannya mendorong pemilik stasiun AM untuk beralih siaran FM. (Muhammad Mufid,2007:140-141) 


\section{Kelebihan Radio}

\section{- Radio Siaran Bersifat Langsung}

Sifat langsung dari radio siaran ini sering pula dirasakan kemanfaatannya oleh kita bangsa Indonesia. Karena sifat langsung radio siaran inilah, Penyiar Radio Bnadung Sakti Alamsyah berhasil membaca naskah proklamasi kemerdekaan pada tanggal 17 Agustus 1945 malam hari keseluruh dunia dalam cekaman ketakutan akan serdadu-serdadu Jepang yang bengis. Karena sifatnya yang langsung pulalah Bung Tomo pada saat meletusnya revolusi Indonesia dengan radio pemberontaknya berhasil membakar semangat pemudapemuda kita sehingga Belanda merasa kewalahan terhadap perlawanan rakyat Indonesia dimana-mana.

Faktor tersebut tidak saja penting dan terasa manfaatnya pada waktu-waktu perang atau revolusi, melainkan juga pada waktu-waktu biasa. Bandingkan pemberitaan melalui surat kabar dan melalui radio siaran peristiwa tertembak matinya presiden Kenedy akan memerlukan waktu yang lama apabila pemberitaannya dilancarkan melalui penerbitan cetak. Akan tetapi melalui radio siaran dapat diberitakan bukan saja pada hari itu tetapi pada jam itu juga dapat diketahui oleh seluruh dunia.

Demikian kompleksnya penyebaran berita dengan surat kabar. Dengan medium radio jauh lebih mudah dan cepat. Tinggal menyusun saja sejarah singkat (berita radio harus singkat dan padat), lalu menyerahkan kepada penyiar untuk dibacakan pada masa siaran berita terdekat. Berita radio dibacakan setiap jam bahkan kalau beritanya sangat penting dapat disiarkan "stop-press" ditengah-tengah acara siaran apa saja dan secara berulang kali.(Muhammad Mufid,2007:25-27)

\section{- Radio Siaran Menembus Jarak dan Rintangan}

Selain waktu, ruangpun bagi radio siaran tidak merupakan masalah. Bagaimanapun jauhnya sasaran yang dituju, dengan radio dapat dicapainya, gunung-gunung, lembahlembah, padang pasir maupun lautan luas semuanya tidak menjadi rintangan.

Kita di Indonesia dengan mudah dapat menikmati pilihan pendengar yang disiarkan radio Australia atau mengikuti berita hangat dari suara Amerika atau kalau tidak senang, dalam beberapa detik saja dapat memindahkan jarum gelombang untuk mendengarkan komentar dari BBC London. Dari Benua Australia pindah ke Benua Amerika, lalu pindah lagi ke Eropa; ini dapat dilakukan hanya dalam beberapa detik saja. Jarak tidak menjadi soal dan rintangan; dapat ditembus.

- $\quad$ Radio Siaran Mengandung Daya Tarik 
Daya tarik ini ialah disebabkan sifatnya yang serba hidup berkat tiga unsur yang ada padanya, yakni : musik, kata-kata dan efek suara.Pesawat radio yang kecil dan harganya relatif murah itu dapat memberikan hiburan, penerangan dan pendidikan. Sedang untuk menikmatinya, yang dengan hanya indera telinga, sipemilik pesawat radio dapat melakukannya sambil duduk, sambil minum, sambil makan, sambil tidur-tiduran atau sambil bekerja.

Studio radio menyajikan berbagai macam programa untuk memenuhi indera pendengar : pria, wanita, tua, muda dan anak-anak. Bukan saja music dan wartaberita, tetapi juga sandiwara, langen suara, taman pramuka, taman kanak-kanak, ruang wanita, ruang sastra, komentar, reportage, ulasan pers, siaran masjid, siaran gereja, siaran mahasiswa, siaran ABRI, dan banyak lagi acara guna memenuhi selera semua golongan dalam masyarakat.

Tulang punggung radio siaran adalah musik. Orang menyetel pesawat radio terutama untuk mendengarkan musik, karena musik merupakan hiburan. Berbagai programa diolah dan diberi ilustrasi. Selain wartaberita (straighnewscast), juga disajikan acara pemberitaan yang diolah dan dihiasi musik dan efek suara (suara pesawat terbang, kereta api, anak nangis, hiruk pikuk orang-orang, petir, hujan, ayam berkokok, dan lain-lain seperti umpama newsreel. Juga sandiwara radio, langen suara, dongeng anak-anak, cerdas tangkas, dan sebagainya diolah dan diberi hiasan agar menarik dan menjadi "hidup".

Demikian pula dalam rangka melancarkan kegiatan propaganda, pertama-tama dihidangkan musik untuk memikat perhatian. Ditengah-tengah musik itulah, jadi pada saatsaat perhatian pendengar tengah terpikat, dilancarkan propaganda.

\section{- Lambang komunikasi radio bersifat auditif}

Yakni terbatas pada rangkaian suara atau bunyi yang hanya menerpa indera telinga. Oleh karena itu radio tidak menuntut khalayak untuk memiliki kemampuan membaca dan kemampuan mendengar, melainkan sekedar memiliki kemampuan mendengar.

- Radio dapat menembus semua pelosok desa

Hal ini dikarenakan daya jangkauannya tidak mengenal batas-batas geografi

- $\quad$ Radio merupakan media yang murah

Bagi penyelenggara pembangunan maupun bagi khalayak

- Seseorang yang mendengarkan radio akan terlibat secara personal

- Siaran dapat dilaksanakan sepanjang hari

- Ringan dan dapat dibawa kemana-mana

- Dapat dinikmati dalam berbagai suasana oleh siapapun (Amri Jahi,1993:23)

- Biaya iklan murah 
Biaya pembuatan program maupun iklan cenderung lebih murah dengan tenggang waktu pembuatan juga hanya sebentar. Sehingga, apabila ada perubahan bisa dilakukan dengan waktu yang relatif cepat pula (ada fleksibilitas)

- Selektifitas

Audience sangat selektif karena setiap station radio sudah terbagi dalam berbagai format station yang menyesuaikan dengan kebutuhan audience.

- Promosi terpadu

Radio memiliki keterpaduan yang unik antara program acara, penyiar, penggemar dan komunitasnya. Keterpaduan ini bisa dimanfaatkan untuk melakukan promosi secara terpadu.

- Mencapai khalayak yang tersegmentasi

Kekuatan utama pertama dari radio adalah bahwa radio hanya menempati urutan kedua setelah majalah dalam kemampuannya untuk menjangkau khalayak yang tersegmentasi. Suatu program radio yang sangat bervariasi memungkinkan para pengiklan untuk memilih format-format dan stasiun-stasiun khusus agar sesuai dengan komposisi khalayak sasaran dan strategi pesan kreatif mereka.

- Mencapai calon pelanggan pada tingkat perorangan dan akrab

Para pedagang dan penyiar radio setempat kadang-kadang ada yang sangat menawan dan meyakinkan. Pesan-pesan mereka muncul seolah-olah mereka berbicara kepada khalayak secara pribadi.

- Ekonomi

Berdasarkan CPM khalayak sasaran, periklanan radio jauh lebih murah daripada media massa lainnya. CPM adalah consumer process model merupakan salah satu model yang memperlihatkan bagaimana konsumen memproses informasi dan memilih berbagai alternative di pasaran dengan berdasarkan pada hal yang rational, kognitif, sistematis dan beralasan.

- Mampu mentransfer cerita atau gambar-gambar (images) dari televisi

Suatu kampanye periklanan televise yang mengesankan dan telah diudarakan akan membangun asosiasi mental pada konsumen antara unsur-unsur penglihatan dan suara di dalam iklan. Citra yang berada dalam pikiran ini kemudian dapat disalurkan ke iklan radio dengan menggunakan suara TV atau suatu adaptasinya. Pengiklan memperoleh manfaat periklanan TV dengan biaya radio yang lebih murah. (A. Terence Shimp,2003:527-528)

Morrisan menyebutkan hal ini sebagai mental imagery, dimana radio memang tidak memiliki kemampuan menunjukkan sebagaimana media yang memiliki kemampuan visual 
lainnya namun iklan radio dari suatu produk yang sebelumnya telah ditayangkan di televise akan membuat orang membayangkan gambaran visual sebagaimana yang dilihatnya di televise.

\section{Kelemahan Radio}

- Penggunaan radio sebagai media penghibur.

Sehingga waktu yang disediakan untuk siaran musik popular dan drama lebih banyak daripada untuk siaran pendidikan

- Isi/materi siaran harus sesuai dengan kebutuhan masyarakat.

Materi berkaitan dengan tingkat pendidikan masyarakat. Isi/materi yang rumit akan menyebabkan kebosanan bahkan tidak dapat dimengerti oleh masyarakat.

- Perpecahan (fragmentasi/fraksionalisasi) khalayak

Banyaknya radio dan program acara yang berbeda-beda membuat audience menjadi terpecah dalam kelompok yang lebih kecil.

- Perhatian terbatas

Mendengarkan radio biasanya menjadi kegiatan selingan yang dilakukan sambil mengerjakan pekerjaan lain. (Morissan,2009:196-197)

- Clutter (ketidakberaturan)

Adanya clutter (ketidakberaturan) radio dengan persaingan iklan lain dan bentukbentuk gangguan dalam modulasi, obrolan, dan gangguan lainnya.

- Tidak dapat menggunakan visualisasi

Banyak kampanye periklanan menggunakan radio hanya sebagai pelengkap dari media lainnya dan bukan sebagai media yang berdiri sendiri. Hal ini mengurangi tugas radio untuk menciptakan citra visual tetapi untuk mengaktifkan kembali citra yang sudah tercipta melalui televise atau majalah. ( A. Terence Shimp,2003:529)

\section{- $\quad$ Kesulitan membeli waktu radio}

Hal ini terjadi karena tidak adanya standarisasi harga di radio, dimana masing-masing radio menetapkan sendiri harga.

Kata media berasal dari bahasa latin, median, yang merupakan bentuk jamak dari medium. Secara etimologi yang berarti alat perantara. Wilbur Schramn mendefinisikan media sebagai teknologi informasi yang dapat digunakan dalam pengajaran. Adapun yang dimaksud dengan media ( wasilah ) dakwah yaitu alat yang dipergunakan untuk menyampaikan materi dakwah (ajaran Islam) kepada mad'u.

Media massa dapat dibedakan kedalam media elektronik seperti : Radio, TV, Film dan media cetak seperti : Surat kabar, Majalah, Pamflet, Buku dan lain-lain.Radio sebagai salah 
satu media massa memiliki karakteristik cepat dalam menyampaikan pesan, luas jangkauannya dalam arti tidak mengenal medan, tidak terikat waktu, ringan dan dapat dibawa kemanapun, murah dan tidak memerlukan banyak konsentrasi karena radio hanya untuk didengarkan.

Dengan banyaknya media yang ada, maka $d a^{\prime} i$ harus memilih media yang paling efektif untuk mencapai tujuan dakwah. Beberapa hal yang perlu diperhatikan pada waktu memilih media adalah sebagai berikut :

1. Tidak ada satu media pun yang paling baik untuk keseluruhan masalah atau tujuan dakwah. Sebab setiap media memiliki karakteristik (kelebihan, kekurangan, keserasian) yang berbeda-beda.

2. Media yang dipilih sesuai dengan tujuan dakwah yang hendak dicapai

3. Media yang dipilih harus sesuai dengan kemampuan sasaran dakwah.

4. Media yang dipilih harus sesuai dengan materi dakwahnya.

5. Pemilihan media hendaknya dilakukan dengan cara objekatif, artinya pemilihan media bukan atas dasar kesukaan $d a ' i$.

6. Kesempatan dan ketersediaan media perlu mendapat perhatian.

7. Efektifitas dan efisiensi harus diperhatikan.

Dakwah melalui radio artinya memperlakukan dan memanfaatkan media paling populer di dunia ini seperti : channel, sarana, atau alat untuk mencapai tujuan dakwah. Jenis program dakwah di radio, selain ceramah dan dialog islam (talk show), materinya terjemahan hadist, ayat Al-Quran, ungkapan sahabat Nabi SAW, nasihat ulama, atau mutiara kata islami. Di tengah keasyikan menikmati misalnya lagu-lagu pop indonesia, para pendengar "didakwahi”" secara "tidak sadar".

Para da'i dan lembaga-lembaga dakwah harus memanfaatkan radio untuk menebarkan risalah islam. Karena itu da'i harus dibekali ilmu dan teknik siaran (announcingskill) agar mampu siaran layaknya penyiar profesional. Alternatif lain, lembaga dakwah membuat paket-paket program religius seperti drama radio,feature, atau sekedar insert/spot renungan islami yang dikemas semenarik mungkin untuk disiarkan diradio.

Media radio terbukti efektif sebagai sarana komunikasi massa yang bisa menjangkau seluruh lapisan masyarakat dan menembus batas, terlebih dengan adanya fasilitas streaming (internet). Radio dakwah sangat prospektif mendatangkan iklan, khususnya produk-produk islami. Dakwah merupakan suatu usaha untuk mengajak, menyeru dan mempengaruhi manusia agar selalu berpegang pada ajaran ALLAH SWT guna 
memperoleh kebahagiaan hidup di dunia dan akhirat. Mengajak ke jalan ALLAH wajib hukumnya. Keberhasilan ajakannya mencerminkan prospek dan pelestarian perkembangan islam di masa mendatang, sebab maju dan mundurnya agama terletak di tangan penganut-penganut-NYA.

Disinilah, maka bimbingan dan penyuluhan agama berperan dalam membangkitkan daya rohaniyah manusia melalui iman dan ketaqwaan kepada ALLAH SWT. Di samping itu, sebagai landasan proses kegiatan dakwah dan penerangan agama yang harus di laksanakan dalam berbagai lapisan masyarakat. Oleh karena itu, sebagai sarana penyiaran agama radio juga dapat memberikan rangsangan terhadap persepsi atau tanggapan dan tingkah laku bagi masyarakat banyak. Masyarakat sensitif terhadap informasi, bahkan menjadi salah satu kebutuhan pokok selain kebutuhan sandang dan pangan. Semakin banyak orang yang berhubungan dengan informasi, maka akan semakin banyak pula pengetahuan bagi dirinya.

Dalam menerima pesan dakwah yang disampaikan tentu saja masyarakat berbeda dalam menerimanya. Begitu juga kepastian tingkat efektifitas pemanfaatan media dakwah. Radio dalam proses berbeda dengan keberadaan pada daya serap pemahaman terhadap nilai yang disampaikan melalui masing-masing media dakwah. Dengan demikian radio dalam proses dakwahnya berbeda dengan keberadaan media dakwah lainnya. Misalnya dalam penyiaran-penyiaran yang berupa ceramah tentang keagamaan yang semuanya itu merupakan upaya penyebaran ajaran yang mudah diterima masyarakat sebagai pedoman hidup guna memperoleh kebahagiaan dunia dan akhirat.

Tiga alasan mengapa radio semakin dilirik, karena sifat ketersegeraan (actuality) berita radio yang tersaji secara langsung menjadi primadona karena aktualitas dan objektivitasnya terjamin tanpa rekayasa ulang dari redaktur. Sifat format kemasan ( bodystyle), kemasan berita radio dewasa ini makin bervariasi, sehingga memudahkan pendengar (audien) untuk memilih kemasan yang pas untuk mereka, dan mencatat waktu penyiaran yang sesuai dengan kesibukan mereka. Sifat lokalitasnya sebagai sarana komunikasi publik, radio menganut prinsip segmentasi menurut kedekatan geografis dan prilaku sosial masyarakat sekitarnya. Prinsip ini mengharuskan radio bersifat sangat lokal, dan karena itu radio lebih mampu menyerap lebih dalam aspirasi lokal dan menyiarkannya. 


\section{Proses Siaran dan Penataan Acara Siaran}

\section{1) Proses Produksi Siaran}

Proses produksi siaran terdiri dari: (J. B. Wahyudi.1994:27)

a. Pra produksi

Tahap ini merupakan tahap awal dalam penyiaran bagi seorang produser dan harus dilakukan secara rinci dan baik. Dalam tahapan pra produksi dibagi tiga bagian :

1) Penemuan ide

Tahapan ini dimulai ketika seorang produser menemukan ide atau gagasan, membuat riset dan menuliskan naskah atau meminta penulis naskah mengembangkan gagasan menjadi sebuah riset.

2) Perencanaan

Tahap ini meliputi penetapan jangka waktu kerja, penyempurnaan naskah, pemilihan narasumber dan crew. Selain estimasi dana, penyediaan biaya dan rencana alokasi merupakan bagian dari perencanaan yang perlu dibuat secara hati-hati dan teliti.

3) Persiapan

Tahap ini meliputi pemberesan semua kontrak, perijinan dan surat-menyurat, meneliti dan melengkapi peralatan yang diperlukan. Semua persiapan ini paling baik diselesaikan menurut jangka kerja (time schedule) yang ditetapkan.

Pra produksi, langkah pertama adalah rapat untuk acara produksi dengan melakukan pandangan jauh, pengamatan atau observasi terhadap masa depan, dimana selalu berpegang pada idealisme dan trend masa kini. Langkah yang kedua yaitu job allocation, yang meliputi : penanggung jawabnya siapa, penyiarnya siapa sampai pada pembuatan script atau naskah jadi. Semua hal tersebut termasuk dalam hal perencanaan. Tentunya sudah dengan pertimbangan matang.

Perencanaan merupakan bagian dari standar operasional procedure (SOP) produksi siaran yang harus dipatuhi setiap broadcaster, ( Masduki,2005:46) yang meliputi : planning; perencanaan produksi paket acara produksi melalui diskusi kelompok oleh tim kreatif bersama para pelaksana siaran lainnya. Hasil planning berupa proposal yang memuat nama acara, target pendengar, tujuan dan target, penempatan siar, sumber materi kata dan musik, durasi, biaya produksi, promosi serta para kru yang akan terlibat dalam produksi seperti produser, presenter, operator dan penulis naskah.

Collecting; pencarian dan pengumpulan materi musik dan kata yang dibutuhkan, termasuk menghubungi calon narasumber jika acaranya berupa talk show. Sumber materi dapat berasal dari perpustakaan, media massa atau wawancara dilapangan. 
Hasil collecting berupa setumpuk materi siaran yang memadai dan siap olah untuk produksi acara. Writing; seluruh materi yang diperoleh kemudian diklasifikasikan untuk selanjutnya ditulis secara utuh dalam kalimat yang siap baca atau disusun sedemikian rupa yang dirangkai dengan naskah pembuka-penutup siaran atau naskah selingan. Penulis naskah mengerjakan tugasnya sehingga menghasilkan naskah siaran yang telah diketik dengan rapi dan siap dibacakan dalam siaran.

b. Produksi

Produksi radio adalah seluruh kegiatan siaran yang dapat dilakukan/disiarkan secara langsung (on air) atau tidak langsung (off air). ( J. B. Wahyudi, 1994:27)

Suatu produksi siaran radio adalah hasil kerja sama antara penyiar dan operator, dan kerja sama ini menentukan baik tidaknya suatu produksi siaran. Produksi siaran yang keluar dari main amplifier tadi dapat didengar dengan keras oleh siapa saja diruangan dalam kompleks studio. Akan tetapi, belum bisa dinikmati oleh pendengar dirumah. Baru dapat didengar oleh para pendengar dirumah, kalau sudah dipancarkan oleh pemancar (transmitter).

Dalam rangka memproduksi siaran perlu diperhatikan sifat-sifat yang terdapat dalam radio, diantaranya :

1. Auditori

Sifat radio siaran adalah auditori, untuk didengar, karena hanya untuk didengar, maka isi siaran yang sampai di telinga pendengar hanya sepintas itu saja. Ini lain dengan sesuatu yang disiarkan melalui media surat kabar, majalah atau media dalam bentuk tulisan lainnya yang dapat dibaca, diperiksa dan ditelaah berulang kali.

2. Mengandung Gangguan

Setiap komunikasi dengan menggunakan bahasa dan bersifat massal akan menghadapi dua faktor gangguan. Gangguan yang pertama ialah apa yang disebut "semantic noise factor" dan yang kedua adalah "channel noise factor" atau kadangkadang disebut "mechanic noise factor"

3. Akrab

Radio siaran sifatnya akrab, intim. Seorang penyiar radio seolah-olah berada dikamar pendengar yang dengan penuh hormat dan cekatan menghidangkan acaraacara yang menggembirakan kepada penghuni rumah, sifat ini tidak dimiliki oleh media lainnya kecuali televisi. ( Onong Uchjana Effendy, 1990:72-76)

Dalam hal ini, untuk menyajikan produksi program yang layak untuk disiarkan. Radio perlu memiliki format penyajian yang terbagi kedalam penggolongan sebagai berikut : 
a. Siaran informasi, format ini dipakai oleh stasiun yang memahami informasi sebagai materi utama siarannya. Informasinya selalu diaktualisasikan, berdasarkan perkembangan peristiwa yang baru terjadi. Format siaran radio ini mengisi kebutuhan masyarakat akan hiburan lewat radio.

b. Siaran informasi musik, format siaran ini memakai perbandingan $60-70 \%$ informasi dan 30-40\% musik. Siaran informasinya menyisipkan musik sebagai selingan, namun dengan titik berat pada unsur informasi sebagai target siarannya.

c. Siaran musik, format siaran radio ini mencirikan stasiun radio yang menekankan musik sebagai piranti utamanya.

Ada dua bentuk proses produksi acara radio, terutama setelah proses penulisan naskah selesai, yaitu (1) on air, produksi dilakukan secara langsung dari ruang siaran, tanpa melalui tahapan pengeditan dan penggabungan materi secara mekanis; (2) off air, produksi dilakukan didalam ruang produksi yang meliputi sejumlah tahap sampai sebuah paket acara siap disiarkan. Pada umumnya untuk paket acara yang disiarkan seminggu sekali dan untuk menghasilkan kesempurnaan auditif, produksi acara dilakukan secara off air.

Didalam standar operasional procedure (SOP) disebutkan sebelum on air akan ada yang namanya vocal recording, perekaman suara presenter yang membacakan naskah buatan penulis naskah di ruang rekaman. Mixing; penggabungan materi vocal presenter dengan berbagai jenis musik pendukung dan lagu oleh operator atau mixerman dengan perangkat teknologi analog atau digital sehingga menghasilkan paket acara yang siap siar. Proses ini dilakukan dengan memperhatikan standar kemasan setiap acara. On air; penayangan acara sesuai jadwal yang telah direncanakan. Khusus untuk produksi siaran yang bersifat langsung (live), tidak perlu vocal recording terlebih dahulu. Proses itu dilakukan bersamaan dengan mixing saat on air oleh penyiar bekerja sama dengan operator.

Setiap perencanaan produksi baik talk show maupun infotaiment haruslah mengahsilkan sebuah usulan dalam bentuk proposal ringkas meliputi (1) topik apa yang dipilih, dirumuskan dalam satu kalimat pendek; (2) latar belakang atau pemaparan kondisi objektif yang menyebabkan pentingnya membahas topik, dirumuskan dalam tiga sampai lima kalimat pendek; (3) rumusan masalah, biasanya dalam bentuk daftar persoalan pokok yang hendak digali dari narasumber dan pendengar; (4) uraian seputar apa saja manfaat mengupas topik bagi pendengar; (5) narasumber dan sumber data yang akan dicari dan dikontak; (6) kru pelaksana mulai dari produser hingga operator; (7) durasi waktu dan 
jadwal penyiaran dan (8) uraian proses pengelolaan acara sejak menit pertama hingga terakhir (run down) mencakup pembahasan inti dan selingan.

c. Pasca Produksi

Dalam pasca produksi yang perlu dilakukan adalah evaluasi dari hasil produksi baik secara on air atau off air. Jika produksi siaran dilakukan secara off air maka perlu editing. Adanya evaluasi dilakukan untuk pembelajaran sehingga pada waktu perencanaan produksi ulang diharapkan hasilnya lebih baik dari produksi sebelumnya. (J. B. Wahyudi, 1994:27)

\section{2) Penataan Acara Siaran}

Menata program adalah kegiatan meletakkan atau menyusun berbagai program pada suatu periode yang sudah ditentukan. Dalam hal ini, pengelola program harus cerdas menata program dengan melakukan teknik penempatan acara dengan sebaik-baiknya untuk mendapatkan hasil yang paling optimal. Penempatan acara yang kurang baik membuat program itu menjadi sia-sia. Pengelola program juga harus memerhatikan berbagai ketentuan yang berlaku ketika menata programnya.

Bagian program harus menganalisis dan memilah-milah setiap bagian waktu siaran untuk mendapatkan berbagai audien yang diinginkan, karena jam yang berbeda akan mendapatkan audien yang berbeda pula. Kalangan yang berbeda menonton di waktu yang berbeda. Jika audien yang menjadi sasaran adalah para remaja, maka jangan memutar acara itu selama jam sekolah atau pada saat larut malam. Jika audien sasaran adalah laki-laki dan perempuan semua umur, maka perlu dipertimbangkan untuk meletakkan acara tersebut pada jam tayang utama (prime time).

Programmer harus menentukan sasaran audien secara realistis. Tidak ada gunanya mencoba menarik audien yang tidak bisa menonton pada saatnya. Siaran berita sangat penting, di pagi hari, tengah hari, malam hari dan tengah malam. Tetapi siaran berita menjadi sia-sia bila ditayangkan sesudah pagi menjelang siang dan di senja hari sebelum malam. Namun perlu diingat program berita tidak dapat bersaing dengan waktu tayang utama acara-acara hiburan, kecuali suatu peristiwa besar tengah berlangsung yang biasanya ingin segera diketahui masyarakat.

Salah satu ciri media penyiaran adalah sifat siarannya yang berlangsung terus-menerus. Media massa lainnya, seperti surat kabar, majalah atau buku sampai ketangan masyarakat dalam satu unit paket utuh. Pembaca majalah tidak harus membaca saat itu juga, ia masih dapat menundanya sampai nanti. Namun stasiun penyiaran menyajikan berbagai menu 
program secara berkesinambungan tanpa terputus. Karenaa alasan inilah maka penataan acara menjadi sangat penting. Pengelola program harus menyusun atau menata program sebaik mungkin, untuk itu ia harus memiliki strategi menata acara (scheduling strategies).

Dalam menyusun jadwal acara, programmer harus mempertimbangkan berbagai faktor yang memengaruhi kebiasaan menonton audien seperti mobilitas audien, jenis pekerjaan, kebutuhan dan ketertarikan audien kepada hal-hal tertentu berdasarkan siklus harian, mingguan, bulanan dan seterusnya. Hal lain yang perlu diperhatikan adalah persaingan atau kompetisi dari stasiun lainnya, yaitu dengan melakukan perubahan jadwal acara, jika perlu, sebagai salah satu bentuk strategi dalam penataan acara. ( Morissan,2009:303-304)

\section{Tugas dan Pekerjaan Penyiar}

Menurut Onong Uchjana Effendy dalam bukunya "Radio Siaran - teori dan praktek "mengatakan: penyiar adalah orang yang menyajikan materi siaran kepada para pendengar". Penyiar bertanggung jawab atas siaran yang menjadi tanggung jawabnya sesuai pengarahan pimpinan/penanggung jawab, dengan perincian tugas sebagai berikut: membuat rancangan/perencanaan materi pendukung siaran sesuai tanggung jawabnya melakukan kegiatan siaran sesuai dengan tanggung jawab yang dibebankan.

Menjadi seorang penyiar harus bisa "terdengar pintar" dan "terdengar menyenangkan" Terkadang, dalam stasiun radio skala kecil (radio komunitas, radio lokal yang belum berkembang), seorang penyiar harus mampu melakukan berbagai tugas lain, seperti merangkap sebagai music director (menyusun playlist lagu).

Kinerja penyiar radio saat ini lebih berat dan kompleks jika dibandingkan dengan kinerja penyiar radio dimasa yang lalu. Penyiar radio masa kini tidak hanya terbatas berbicara di depan mickrofon, malainkan harus mempersiapkan segala macam persiapan sebelum menjalankan tugas siaran, termasuk mempersiapkan materi atau bahan siaran. Keberhasilan penyiar radio dalam membawakan program acara tertentu tidak terlepas dari kedisiplinan penyiar dalam mempersiapkan diri.

Penyiar (announcer) radio memilki tugas-tugas yang menunjang profesinya, anatara lain :

1. Mempersiapkan materi siar yang akan digunakan sebagai bahan siaran dalam bentuk "rencana siar" walaupun beberapa radio siaran sudah menempatkan script writer untuk membantu penyiar radio.

2. Disiplin dalam tugas siaran.

3. Bertanggung jawab atas isi dan materi siaran yang dibawakan saat siaran di stasiun radio.

4. Bertanggung jawab atas berlangsungnya suatu program acara di stasiun radio. 
5. Bertugas dan bertanggung jawab terhadap pemutaran spot iklan sponsor dan mencatatnya sebagai bukti siar.

6. Mengamati dan mencatat peristiwa/kejadian selama menjalankan tugas sebagai penyiar.

7. Menjaga nama baik perusahaan dimana dia bekerja sebagai penyiar radio.

8. Mengantar rekaman lagu/musik dan program.

9. Membacakan iklan-iklan (live comercials), layanan publik dan identifikasi stasiun.

10. Menyampaikan laporan/informasi waktu, cuaca dan lalu lintas.

11. Menjalankan peralatan control room.

Sebagai tambahan, penyiar juga dapat melakukan hal-hal lain sebagai berikut :

1. Ikut serta memproduksi iklan dan pengumuman.

2. Bertindak sebagai pengisi suara untuk iklan dan pengumuman lainnya.

3. Membantu music director serta manajer produksi. ( Morissan, 2009:288)

Selain tugas-tugas di bidang penyiaran, masih ada beberapa tugas lain yang harus dilaksanakan oleh penyiar radio, seperti reportase, wawancara, talk show dan lain-lain. 


\section{DAFTAR KEPUSTAKAAN}

Morissan, Manajemen Media Penyiaran Strategi Mengelola Radio \& Televisi,Jakarta : Kencana, 2009

Shalehuddin, Komunikasi dan Regulasi Penyiaran, Jakarta : Kencana, 2007

Burhan Bungin, Teknik Praktis Riset Komunikasi, Jakarta : Kencana, 2007 Bakti, 2003

Onong Uchjana Effendy, Ilmu, Teori dan Filsafat Komunikasi, Bandung : PT Citra Aditya

Muhammad Mufid, Komunikasi dan Regulasi Penyiaran, Jakarta : Kencana, 2007

Syukur Kholil, Teori Komunikasi Massa, Bandung : Cita Pustaka Media Perintis, 2011 Bakti, 200

Onong Uchjana Effendy, Ilmu Teori dan Filsafat Komunikasi, Bandung : Citra Aditya

Syukur Kholil, Komunikasi Islami, Bandung : Cita Pustaka Media Perintis, 2007

Jalaluddin Rakhmat, Psikologi Komunikasi, Bandung : Rosda Karya, 2007

Nuruddin, Pengantar Komunikasi Massa, Jakarta : Raja Grafindo Persada, 2007

Onong Uchjana Effendy, Televisi Siaran Teori dan Praktek, Jakarta : Mandar Maju, 1993

Amri Jahi, Komunikasi Massa dan Pembangunan, Jakarta : Yayasan Obor Indonesia, 1993

A. Terence Shimp, Periklanan Promosi Aspek Tambahan Komunikasi Pemasaran Terpadu, Edisi kelima, Jakarta : Erlangga, 2003

Morissan, Manajemen Media Penyiaran : Strategi Mengelola Radio dan Televisi, Jakarta : Kencana, 2009

J. B. Wahyudi, Dasar-Dasar Penyiaran, Jakarta : Gramedia Pustaka Utama, 1994

Masduki, Menjadi Broadcaster Profesional, Jakarta : Gramedia Pustaka Populer, 2005

1994

J. B. Wahyudi, Dasar-Dasar Manajemen Penyiaran, Jakarta: Gramedia Pustaka Utama,

Onong Uchjana Effendy, Radio Siaran (Teori dan praktek), Bandung: CV Mandar Maju, 1978

1990

Onong Uchjana Effendy, Radio Siaran (Teori dan praktek), Bandung : CV Mandar Maju,

J. B. Wahyudi, Dasar-Dasar Penyiaran, Jakarta : Gramedia Pustaka Utama, 1994 